\title{
Utilization of STEM Tools and Workshops to Promote STEM Education in the United States and South Africa
}

\section{Dr. Christina L. Carmen, University of Alabama, Huntsville}

Dr. Carmen obtained a Bachelor of Aerospace Engineering degree as well as a Master of Science in Aerospace Engineering degree from the Georgia Institute of Technology in Atlanta, GA. While at Ga. Tech she worked with Dr. Warren Strahle, researching solid propellants. She obtained a Doctor of Philosophy in Mechanical Engineering from the University of Alabama in Huntsville (UAH) with a focus upon turbulent combustion modeling. Dr. Carmen is the capstone design class coordinator in the Mechanical and Aerospace Engineering (MAE) department at UAH. She primarily teaches MAE senior design classes with a focus upon product realization - a class she has taught for 14 years.

Several of Dr. Carmen's senior design teams have won national and international design competitions including the American Society of Mechanical Engineers (ASME) Safety Engineering and Risk Analysis Division safety competition, the International Aluminum Extrusion Design Competition, the American Astronautical Society/von Braun Symposium student poster competition, the NASA Exploration Systems Mission Directorate (ESMD) Systems Engineering design competition and the NASA Great Moonbuggy Race. In 2012, the UAH Moonbuggy team won 1st place in the Moonbuggy race.

Dr. Carmen is the UAH ASME student chapter faculty advisor as well as a Director of the North Alabama ASME section. Dr. Carmen has served as a National Science Foundation scholarship panelist, Department of Defense SMART scholarship panelist and as a delegate to the ASME Leadership Training conference. In 2010 and 2013, Dr. Carmen was named the Outstanding Mechanical Engineer in North Alabama by ASME. In 2010 she was awarded a NASA Exploration Systems Mission Directorate (ESMD) faculty fellowship - one of 5 senior design class instructors selected from around the country to participate in the program. As a result of the fellowship, several UAH MAE senior design teams have been able to work with NASA engineers on projects that are relevant to NASA's mission. In April 2011, Dr. Carmen was selected as a Society of Automotive Engineers (SAE) Ralph R. Teetor Educational Award recipient.

\section{Mr. Ben Groenewald}




\title{
Utilization of STEM Tools and Workshops to Promote STEM Education in the United States and South Africa
}

\author{
Christina L. Carmen, Ph.D. \\ Mechanical and Aerospace Engineering Department \\ University of Alabama in Huntsville \\ Huntsville, Alabama, USA \\ Ben Groenewald \\ Electrical, Electronics, and Computer Engineering Department \\ Cape Peninsula University of Technology \\ Cape Town, South Africa
}

\begin{abstract}
In 2012, an academic partnership was established between the Cape Peninsula University of Technology (CPUT) in Cape Town, South Africa and the University of Alabama in Huntsville (UAH) in Huntsville, Alabama (AL). This joint effort was termed the ALLiance for International Excellence among the future Space workforce, or ALLIES. Initially, the ALLIES partnership was centered within engineering design classes at CPUT and UAH. Engineering design tools and methodologies were shared as well as the establishment of a focus upon the design and development of Science, Technology, Engineering, and Mathematics (STEM) tools created by the CPUT and UAH engineering students. The STEM tools are intended to provide kindergarten-through-grade-twelve (K-12) students, both in the United Sates (US) and South Africa, an intuitive, hands-on learning experience in order to encourage the younger students to pursue a STEM education and, ultimately, a STEM career. During the design process, the engineering design students visit the K-12 schools in order to incorporate the design suggestions of the younger students and teachers as well as ensure that the STEM tools provide an understanding of a required learning outcome specified within the curriculum. Thus far, as a result of the ALLIES collaboration, three STEM tools have been developed and donated to schools in both nations: a catapult and two table top wind tunnels. While the catapult was donated to a school in South Africa and the wind tunnels were donated to schools in the US, all three STEM tools were designed and fabricated with input from both CPUT and UAH engineering design students. In 2013, the ALLIES effort expanded beyond the design and development of STEM tools to include workshops aimed at motivating and inspiring undergraduate students and educators throughout the Cape Town, South Africa region to pursue their own STEM initiatives. The workshop focused upon the need to further develop the future STEM workforce and provide guidelines for proactively integrating STEM initiatives within K12 schools and universities. During the workshop, audience members also engaged in a brief space-related design project that can be tailored to any age bracket. The present paper will provide a brief overview of the STEM tools that have been created thus far, with a focus upon the details and impact of the STEM outreach workshop conducted in South Africa. Data has been garnered that details the learning outcomes and benefit of the STEM tools upon US and South African students as well as the impact of the STEM workshop upon educators in South Africa.
\end{abstract}




\section{Keywords}

Capstone Design, Engineering Design, STEM Tools, STEM Outreach, International Design Collaboration

\section{Introduction}

The US is increasingly placing greater emphasis upon the promotion of STEM education and outreach efforts in order to meet the growing demand for STEM workers. The need to grow the US STEM workforce has been well documented. The Space Foundation-a global, non-profit organization that provides industry data and statistics-reported the following data in its 2014 Space Report ${ }^{1}$ :

- The US space workforce declined 3.5\% from 2011 to 2012

- At the start of fiscal year 2014, the number of National Aeronautics and Space Administration (NASA) employees eligible to retire was greater than the number of employees younger than age 35

- As of September 2011, more than 30\% of the broader US Department of Defense civilian STEM workforce was eligible to retire

- In 2012, European space industry employment increased by $1.5 \%$ and Japanese space industry employment grew by $11 \%$

In 2013, in order to address the need to continue to build the future STEM workforce pipeline, US President Obama's administration released a report ${ }^{2}$ specifying a five year strategic plan for STEM education. The report detailed the need for increased efforts to build the future US STEM workforce and identified five key areas of priority investments including the following:

1) Improve STEM Instruction

2) Increase and sustain youth and public engagement in STEM

3) Enhance the STEM experience of undergraduate students

4) Better serve groups historically underrepresented in STEM fields

5) Design graduate education for tomorrow's STEM workforce

One of the results of this strategic plan is a Fiscal Year 2015 US Department of Education budget that allots approximately 320 million US Dollars (USD) to pre-kindergarten-throughgrade-twelve (P-12) STEM education and learning, and over 152 million USD to support STEM education at the undergraduate level and beyond ${ }^{3,4}$.

The nation of South Africa is also accelerating emphasis upon STEM education and careers among its K-12 population. During a 46 year period, from 1948 to 1994, apartheid existed whereby a majority of the nation's population experienced educational discriminationmathematics and science were no longer provided within the educational curriculum. Apartheid categorized each South African citizen into one of four groups; "Whites", "Indians", "Coloreds", and "Blacks", whereby the privileges and status of each group decreased in alignment with the aforementioned order. Even though South Africa has made great strides since 1994, the legacy of such an extended period of educational discrimination has kept South Africa from reaching its full potential. For example, in 1993, the year before apartheid was dismantled, Blacks and Coloreds accounted for $9 \%$ and $13 \%$, respectively, of the STEM, business, and commerce population $^{5}$. Yet, in 2007, the participation rate of these groups was still only at $12 \%$ each. On the other hand, Whites and Indians accounted for $40 \%$ and $70 \%$, respectively, of the STEM, 
business, and commerce population in 1993, and still accounted for $43 \%$ and $54 \%$, respectively, in $2007^{5}$.

Independently, C. Carmen of UAH and B. Groenewald of CPUT had already been involved in long-standing efforts to promote STEM education within their respective nations ${ }^{6}$, before meeting in 2011 at an international conference. Upon meeting, both educators decided that an international collaborative effort would not only promote STEM in the US and South Africa, but also enable students at UAH and CPUT to garner invaluable international design experience. As a result, the ALLIES partnership commenced in 2012.

\section{Background}

The ALLIES partnership was initiated in order to provide undergraduate engineering students the opportunity to engage in an international design effort. In order to address the need to promote STEM education and careers among K-12 students, the ALLIES design efforts result in the creation of STEM tools donated to primary or secondary education classrooms in the US and South Africa. The design effort takes place within capstone design classes that are typically comprised of students completing their final year of an undergraduate engineering program. The capstone class is the culminating class in an engineering curriculum whereby students apply their education and knowledge gained in order to design an engineering system.

Thus far, the ALLIES effort has been implemented in capstone classes at UAH and CPUT; specifically, within the Mechanical and Aerospace Engineering (MAE) department Product Realization design class at UAH, and the Electrical, Electronics, and Computer Engineering (EECE) department design class at CPUT. Since the 2012 inaugural year of the ALLIES partnership, three phases have been completed. An overview of the three phases is provided in Table 1.

Table 1. ALLIES Phase Objectives

\begin{tabular}{|lll|}
\hline Phase I & Jan.-Dec. 2012 & $\begin{array}{l}\text { • UAH and CPUT instructors share and utilize design tools } \\
\text { • Engineering students design and fabricate a STEM tool }\end{array}$ \\
\hline Phase II & May-Dec. 2013 & $\begin{array}{l}\text { • C. Carmen conducts a STEM workshop in South Africa } \\
\text { • Engineering students design and fabricate a STEM tool }\end{array}$ \\
\hline Phase III & May-Dec. 2014 & • Engineering students design and fabricate a STEM tool \\
\hline
\end{tabular}

The overall goal of the ALLIES partnership is focused upon the creation and donation of STEM tools to K-12 classrooms due to the prior success of such ventures within the capstone design class at UAH. Since 2008, numerous STEM tools have been developed at UAH and include the following: fluid flow circuit, interactive solar system, trebuchet, ballistic pendulum, pulley system, water distillation system, fatigue testing machine, and a Wimshurst machine - to name a few. Images of some of the STEM tools designed by UAH engineering design students over the past 7 years are shown in Figure 1. Hands-on STEM tools motivate and engage younger students, as interacting with hardware intuitively reinforces theoretical concepts presented in the classroom. 


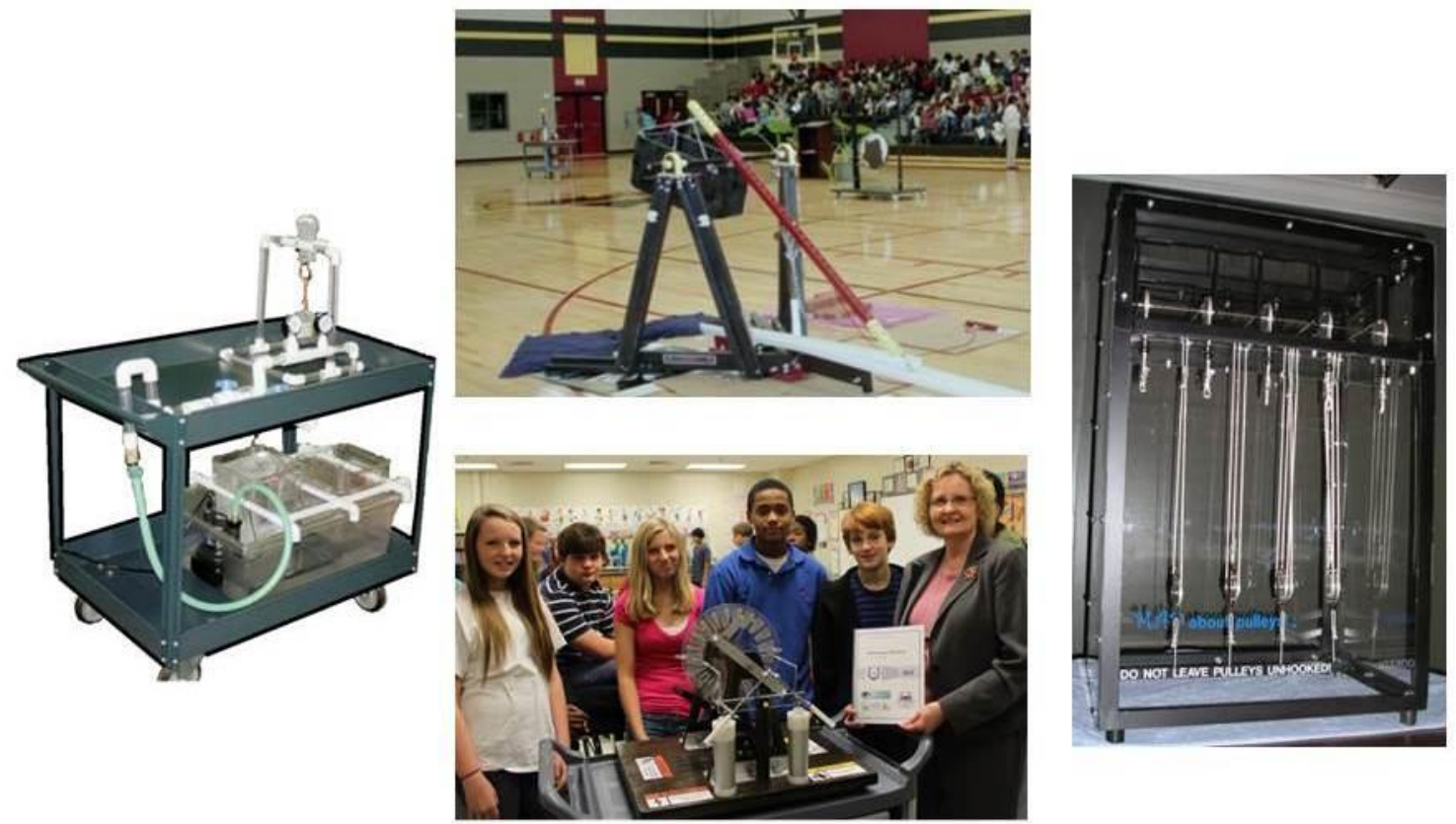

Figure 1. Examples of STEM Tools designed by UAH students (Clockwise from top: catapult, pulley system, Wimshurst machine, and fluid flow circuit)

The typical process utilized by UAH engineering teams when designing and donating STEM tools for K-12 schools is conveyed in Figure 2. As much as was allowable with an international STEM tool design effort, this project process was the basis of the development of the ALLIES STEM tools as well. This process has been described in detail ${ }^{7}$ and the following is a brief overview:

1. A K-12 school is identified and contacted in order to establish interest in receiving a STEM tool. Typically, a STEM field teacher in the school is the primary point of contact and specifies concepts that the STEM tool should convey.

2. With the initial request, desires, and STEM tool requirements provided by the K-12 school and teacher(s), the engineering design students develop initial concepts and visit the K-12 classroom. During the initial visit, the engineering students introduce themselves and present early design efforts. Additionally, a market survey is administered to the K-12 students and teacher(s), in order to involve them in the design process and specifics of the resulting STEM tool. Market survey questions range from "what color would you like the product to be?" to more technical questions such as "would you like the product to be powered by direct current or alternating current?"

3. Throughout the design process, the K-12 teachers and students are kept apprised of the design process via classroom visits or formal design review attendance. Typically, the K12 teacher attends the formal engineering design team reviews and reports the status to his or her students.

4. Upon completion of the STEM tool, arrangements are made with the K-12 teacher such that the engineering design team visits the recipient classroom. However, before the engineering students discuss and demonstrate the STEM tool, a "pre-survey" is administered. The "pre-survey" primarily consists of questions pertaining to particular learning outcomes and phenomena that the STEM tool will demonstrate. 
5. The engineering design students conduct a Microsoft ${ }^{\circledR}$ Power Point ${ }^{\circledR}$ presentation whereby the design process is discussed and pictures are shown of the manufacturing, assembly, and testing of the final STEM tool. After the presentation, the engineering students discuss and demonstrate the completed STEM tool to the students and teacher.

6. At the end of the classroom visit, a "post-survey" is administered to the K-12 students. The questions are identical to those on the "pre-survey" in order to gauge the K-12 students' learning outcome as a result of the presentation and STEM tool demonstration. The STEM tool is donated to the school along with a detailed Operations Manual and Lesson Plan (if initially requested by the K-12 teacher).

7. The survey results are evaluated by the engineering design students and capstone design class instructors.



Figure 2. The STEM tool project process utilized within the ALLIES partnership

While the primary goals of the ALLIES partnership are to develop the future STEM workforce by inspiring younger students via hands-on STEM tool interaction and enabling international collaboration among the undergraduate engineering students, numerous other benefits have resulted. Some of the benefits include the following: the engineering design students have garnered invaluable experience associated with meeting stakeholder expectations, designing with safety as a top-level requirement, and gaining teaching experience via lessons directed to the K12 students, to name a few. Survey data gathered from the K-12 students clearly indicates that the younger students are inspired and educated about the STEM tool as a result of the ALLIES 
effort. Additional surveys completed by the undergraduate engineering students also reveal the positive impact working on an international design effort has had, as well as the reward of working on a project that motivates K-12 students. The present paper will provide survey results.

The STEM acronym has become well-known and frequently utilized within the US. However, in South Africa many STEM educators, from K-12 through higher education levels, are still not familiar with STEM efforts and, as a result, critical opportunities to promote STEM education are missed. Therefore, during Phase II of the ALLIES partnership it was determined that a STEM workshop, conducted in South Africa, would be of great benefit. The workshop was well-received and proved to be very beneficial-as conveyed by survey data accumulated after the workshop.

\section{Phase I ALLIES Results}

During the 2012 inaugural year of the ALLIES program, emphasis was placed upon two primary tasks: 1) the sharing of design methods and tools, and 2) the design of a STEM tool for use in a South African school. Regarding the sharing of design methods and tools, the UAH and CPUT design instructors determined that since the students involved at CPUT are electrical engineering students and the UAH students are mechanical and aerospace engineering students, a common design tool that could be utilized by different majors was the best option. The selected design tool was an evaluation matrix. The matrix development is described within NASA's Systems Engineering (SE) handbook ${ }^{8}$ which is used within the UAH design class to guide the engineering students through the design process. The matrices allow for comparison of various design concepts via the specification of weighted design criteria that enable each concept to receive a final "score"-with the highest scoring concept, typically, being the best option. A lecture used at UAH that provides details regarding the importance, creation, and use of evaluation matrices was provided to the CPUT instructor to present to the students. The CPUT students were asked to complete a survey before and after the lecture in order to assess the learning outcome and impact of the lecture as well as their understanding of the use of evaluation matrices in the design process. Twenty nine senior electrical engineering students at the CPUT Cape Town campus completed the survey and the results clearly conveyed the positive impact of sharing this particular design tool. Figure 3 provides the survey results of one question that inquired as to whether CPUT students knew what an evaluation matrix is. As can be seen, before the lecture the majority of students did not know what an evaluation matrix is, and after the survey the opposite was true; the majority of students had some level of understanding of evaluation matrices. C. Carmen and B. Groenewald have previously documented details of the additional survey results ${ }^{6}$.

The second goal of Phase I was the design and development of a STEM tool that would be donated to a school in South Africa. The instructors at UAH and CPUT decided that the initial STEM tool should not be too complex in design and should be a tool that can be easily duplicated in both the US and South Africa. The instructors determined that a table top catapult would be an appropriate STEM tool that could be integrated in a South African classroom in order to convey the concepts of potential energy, kinetic energy, launch angles, range, and maximum altitude-among many other teaching lessons that could be implemented. Since the UAH design classes have previously designed and built numerous STEM tools, it was 




Figure 3. CPUT survey question results regarding knowledge of evaluation matrices

determined that the UAH team would design and build the catapult with direct guidance and assistance from the CPUT students. The effort began in late May 2012 with a true international collaborative effort taking place between the UAH and CPUT engineering design students. The entire design process and efforts have been previously provided ${ }^{6}$ and, as a result, only highlights of the Phase I STEM tool design effort will be provided.

The UAH engineering team began the design process by researching various types of catapults while, in adherence to Figure 2, the CPUT students began to identify a K-12 school in South Africa that would receive the STEM tool. Upon completion of the two aforementioned tasks, CPUT students conducted a presentation at a Cape Town, South Africa middle school-as shown in Figure 4-whereby they discussed the initial catapult design concepts and distributed a market survey for the younger students to complete. The market survey details and results have been previously reported ${ }^{6}$. The goal of the market survey was to gather demographics data and allow the middle school students to provide input regarding the design of the catapult. One particular inquiry regarded the type of catapult the younger students would like to have within the

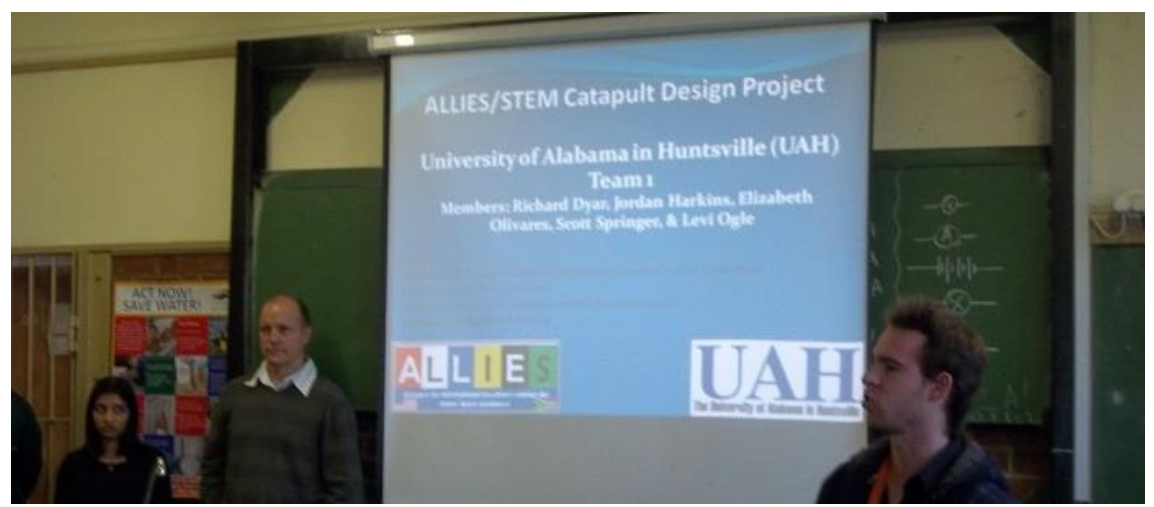

Figure 4. CPUT students discuss the STEM tool catapult a South African middle school 
classroom. The presentation provided by the CPUT students elaborated upon different types of catapults; specifically, ballista, onager, or trebuchet. The survey results shown in Figure 5 indicated that the majority of the 63 middle school students preferred the onager style catapult. As a result, an onager style catapult was designed, built, and completed in Dec. 2012. The final product is shown in Figure 6 along with the Elswood Secondary School (Elsies River, South Africa) students, teacher, and representatives from CPUT.

\section{Catapult Style}



Figure 5. South African middle school survey results regarding the preferred catapult style



Figure 6. Elswood school learners and their teacher, L. Olyn (second row, far left), as well as two CPUT EECE Lecturers, R. Setshedi (second from right) and A. Abrahams (far right) are shown with the ALLIES catapult ${ }^{9}$ (provided by B. Groenewald)

While the overall goals of Phase I were achieved, there were some issues with the project that were, eventually, solved. Specifically, the STEM tool was not able to be delivered to the recipient school in South Africa upon completion in Dec. 2012. The UAH design team researched shipping costs and the lowest estimate to ship the catapult from Huntsville, AL to Cape Town, South Africa was 500 US Dollars. As a result, it was decided that C. Carmen would transport the catapult in May 2013 during a visit to CPUT. Due to time limitations no "pre" and "post" surveys were distributed to the STEM tool recipient school. 


\section{Phase II ALLIES Results}

Due to the success of Phase I, the second phase of the ALLIES partnership commenced in May 2013 with the goals of conducting STEM workshops in South Africa and designing another STEM tool. The STEM workshops would be conducted by C. Carmen with two distinct audiences; South African educators (primary, secondary, and post-secondary) and CPUT students. It was determined that the Phase II STEM tool could be more complex in design as it would be donated to a school in Huntsville, AL and not transported to South Africa.

Two STEM workshops were conducted in May 2013 on the Belleville CPUT campus. The audiences in attendance consisted of CPUT students and staff from the Education, Life Sciences, and Engineering faculties, as well as school principals, and mathematics and science teachers from around the Western Cape region in South Africa. Teachers and administrators representing 65 schools were able to attend the STEM workshop and were provided detailed information with respect to the following: 1) what STEM education entails, 2) why it is important to promote STEM education in South Africa and the US, 3) what type of STEM careers are available, 4) recommended processes for conducting STEM outreach events, and 5) the importance of handson STEM projects. The principals and teachers then conducted a 20 minute design project that could be implemented within primary and secondary education schools. Finally, the attendees were exposed to a demonstration of the Phase I ALLIES STEM tool catapult.

The 20 minute design project that was conducted during the CPUT STEM workshop entailed the design of a "lunar lander." The lunar lander project utilizes simple parts and components, such as straws, cardboard, marshmallows, rubber bands, note cards, and small paper cups, such that teams of 3-6 audience members can design, build, and test their final product. The goal is to design a lunar lander similar to NASA's Apollo Lunar Module (LM) the "Eagle" that touched down on the Moon in 1969. NASA provides information regarding materials and instructions needed for such simple and engaging design projects ${ }^{10}$. Audience members at CPUT were provided information about NASA, the Apollo program, and the original Eagle LM. Audience members were also provided information about the design process and details regarding the goal of the simple 20 minute design project they would undertake. The materials for the design project were pre-packaged and distributed to the each team. The teams were then given 15 minutes to design and build a lunar lander. Afterward, each lunar lander was drop tested in order to determine whether the lander would tip over. Starting from small heights of, roughly, 20 centimetres, each lander was dropped at incrementally larger heights until it tipped over. The lander that was, ultimately, successfully drop tested from the highest distance won the challenge. Shown in Figure 7 is a UAH student drop testing a lunar lander made by a middle school student in Huntsville, AL at a similar STEM outreach event. Four student made landers can be seen in Figure 7. Each lander is different and the opportunities to discuss engineering characteristics of each lander are numerous. For example, one the landers has a high center of gravity. The audience can be asked if this will help or hinder a successful drop test (or landing.) Also, the lander weight can be discussed-greater payload weight is more costly to launch and requires greater rocket thrust to launch into orbit. Such simple design challenges educate and engage students and adults of all ages. 




Figure 7. A UAH student drop tests a "lunar lander" at a middle school STEM outreach event in Huntsville, AL

In order to gauge the workshop attendees' understanding and interest in STEM efforts, two surveys were created by B. Groenewald of CPUT. Upon arrival, but prior to the start of the STEM workshop, 56 educator audience members were administered a "pre-workshop" survey regarding their knowledge of STEM education and interest in pursuing STEM activities. The results of the pre-workshop survey are provided in Table 2 and key findings are listed as follows:

- Less than $18 \%$ had heard of STEM education

- Over 98\% wanted to learn more about STEM education

- Only 4 of the 56 respondents had been exposed to STEM tools

- Over 53\% believed that using STEM tools can improve science and mathematics results in South Africa

After the workshop a "post-workshop" survey was administered to the audience. While 56 respondents completed the "pre-workshop" survey, 72 respondents completed the "postworkshop" survey; this is likely due to late arrivals that did not complete the first survey. The results of the second survey are provided in Table 3 and key findings are as follows:

- $100 \%$ believed STEM education should be part of South African education

- Less than 7\% believed that enough was being done to promote STEM in South Africa

- Over $90 \%$ were interested in being part of a STEM effort

- Over $77 \%$ were interested in being involved in the development of STEM tools

- Over 77\% were interested in developing STEM educational materials

In addition to conducting a STEM workshop in South Africa, the second goal of the ALLIES Phase II effort was the design and fabrication of a second STEM tool. A lesson learned during Phase I was that shipping costs between the US and South Africa are prohibitive. As a result, it 
Table 2. Survey questions administered prior the South African STEM workshop

\begin{tabular}{|c|c|c|c|}
\hline Pre-Workshop Questions & Yes & $\begin{array}{l}\text { Not } \\
\text { Sure }\end{array}$ & No \\
\hline 1.Have you ever heard of STEM Education? & 10 & 10 & 36 \\
\hline 2.Do you know what STEM Education is about? & 12 & 16 & 28 \\
\hline 3.Are you interested to find out more about STEM Education? & 52 & 3 & 1 \\
\hline $\begin{array}{l}\text { 4. Have you ever tried using an interdisciplinary approach to learning (e.g. combining } \\
\text { maths, science, and technology, or history, etc.)? }\end{array}$ & 37 & 8 & 11 \\
\hline 5.Do you ever consider the impact that your subject may have on the future work force? & 51 & 4 & 1 \\
\hline $\begin{array}{l}\text { 6. Do you ever consider the economic value of your subject in the context of the South } \\
\text { African economy? }\end{array}$ & 47 & 6 & 3 \\
\hline $\begin{array}{l}\text { 7. Do you ever consider the economic impact your students may have on the economy } \\
\text { when selecting a career? }\end{array}$ & 50 & 4 & 2 \\
\hline 8.Is your school or programme linked to the private sector? & 18 & 14 & 24 \\
\hline 9.Do you think that your school or programme should be linked to the private sector? & 45 & 9 & 2 \\
\hline 10. Have you been exposed to STEM tools prior to attending this seminar? & 4 & 9 & 43 \\
\hline 11. Have you used STEM tools in your subject before? & 6 & 9 & 41 \\
\hline $\begin{array}{l}\text { 12. Do you think the use of STEM tools can or will make an impact in your teaching } \\
\text { methodology? }\end{array}$ & 26 & 27 & 3 \\
\hline $\begin{array}{l}\text { 13. Do think that STEM tools can contribute towards improving science and } \\
\text { mathematics results at school? }\end{array}$ & 30 & 25 & 1 \\
\hline $\begin{array}{l}\text { 14. Do you think that most educators will see the use of STEM tools as "additional" } \\
\text { work? }\end{array}$ & 19 & 35 & 2 \\
\hline $\begin{array}{l}\text { 15. Do you agree that the use of STEM tools has the potential to increase critical } \\
\text { analysis/thinking in students/learners? }\end{array}$ & 29 & 25 & 2 \\
\hline
\end{tabular}

Table 3. Survey questions administered at the conclusion of the STEM workshop

\begin{tabular}{|c|c|c|c|}
\hline Post-Workshop Questions & Yes & $\begin{array}{l}\text { Not } \\
\text { Sure }\end{array}$ & No \\
\hline $\begin{array}{l}\text { 1. Do you think that STEM Education has a place in the South African Education } \\
\text { System? }\end{array}$ & 72 & 0 & 0 \\
\hline $\begin{array}{l}\text { 2. Do you think enough is being done to promote the understanding of Science, } \\
\text { Technology, Engineering and Mathematics at the school level? }\end{array}$ & 5 & 10 & 57 \\
\hline $\begin{array}{l}\text { 3. If you have the opportunity, would you like to be part of a STEM Education } \\
\text { programme? }\end{array}$ & 65 & 7 & 0 \\
\hline $\begin{array}{l}\text { 4. Would you be interested in joining groups practising the use of STEM tools in } \\
\text { Education? }\end{array}$ & 63 & 9 & 0 \\
\hline 5. Would you like to be involved with groups developing STEM tools? & 56 & 14 & 2 \\
\hline $\begin{array}{l}\text { 6. Would like to be involved in groups who develop educational learning materials } \\
\text { around STEM tools? }\end{array}$ & 56 & 16 & 0 \\
\hline
\end{tabular}


was decided that the STEM tool would be donated to a school in the country in which the tool was fabricated. Additionally, the STEM tools should be designed such they could be replicable in either South Africa or the US. Using the same STEM tool design process as was implemented during Phase I, the UAH and CPUT engineering design students worked closely on the design of a table top wind tunnel. A top-level requirement was that the wind tunnel should be designed with materials and parts available in the US and South Africa. The wind tunnel was fabricated by the UAH students and was demonstrated and donated to Huntsville High School in Huntsville, AL. The engineering students at CPUT were provided with a detailed report that included manufacturing and assembly instructions such that the wind tunnel could be replicated in South Africa and distributed to K-12 schools. The completed wind tunnel is shown in Figure 8 and details regarding the wind tunnel requirements and product specifications have been previously disseminated ${ }^{11}$. The cost to product the Phase II wind tunnel was under 500 USD.

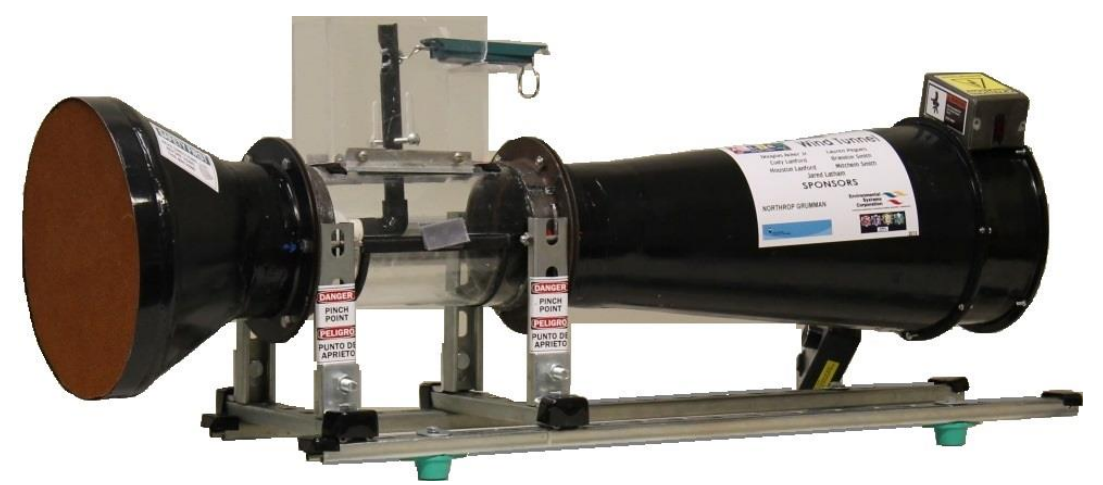

Figure 8. The Phase II ALLIES STEM tool table top wind tunnel (provided by C. Carmen)

\section{Phase III ALLIES Results}

The most recent ALLIES effort, referred to as Phase III, began in May 2014 and was completed in Dec. 2014. The Phase III goals were to expand upon the success of the wind tunnel designed during Phase II. It was determined that a wind tunnel that allowed for visualization of the flow streamlines would be appropriate for all K-12 grade levels. Younger students could visually observe the flow over test articles while older students could still calculate various airflow parameters. As a result, the Phase III wind tunnel, as shown in Figure 9, incorporated a mist



Figure 9. The Phase III ALLIES STEM tool table top wind tunnel (provided by C. Carmen) 
generator that, when mixed with the airflow, allows for visual observation of the flow around a test article. The test article shown in Figure 9 is a sphere and the horizontal flow streamlines are clearly visible ahead of the test article (to the left of the sphere as shown in the image.) The flow streamlines are visibly separated behind the test article (to the right of the sphere as shown in Figure 9.) The final cost associated with the fabrication of the Phase III wind tunnel was just under 800 USD. The UAH design team conducted a presentation for an $8^{\text {th }}$ grade science class at the STEM tool recipient school-St. John the Baptist Catholic School in Madison, AL. As is indicated in Figure 2, the UAH team administered a survey before a discussion and demonstration of the wind tunnel, and a survey after discussion and demonstration. The $8^{\text {th }}$ grade respondents were all 13 or 14 years of age and 13 were female while 6 were male. A total of 12 survey questions were asked and the results of 2 questions specifically pertaining to the wind tunnel are provided in Figure 10. One question inquired whether the students understood the purpose of a wind tunnel and another question asked whether the students knew the difference laminar and turbulent flow. Both survey results demonstrate a significant difference in knowledge and understanding between the survey conducted before the demonstration and the survey conducted after the demonstration.
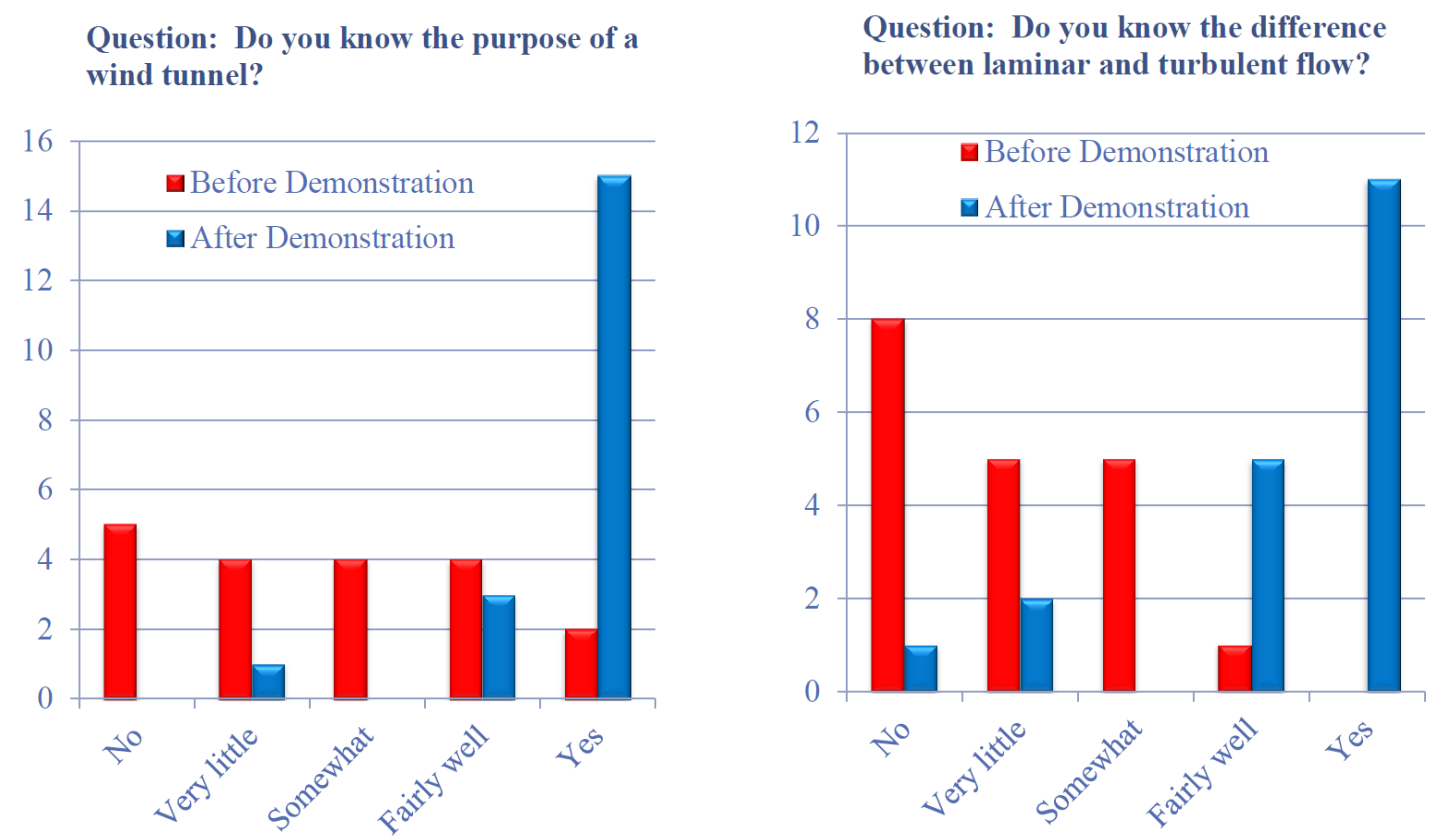

Figure 10. Phase III wind tunnel survey results administered to $8^{\text {th }}$ grade science students

Upon completion of the project, the 5 person UAH engineering design team also completed a survey and the results are provided in Table 4. Overall, the UAH students conveyed their interest in working on an international design project as well as the benefits of developing a STEM tool that could be fabricated for South African students and schools. Since the CPUT students were actively engaged in the design and development of the Phase III wind tunnel, they have the ability to replicate the tunnel-as many times as needed- for donation to schools in South Africa. It is interesting to note that 4 of the $5 \mathrm{UAH}$ students had, previously, never worked on an international design effort. 
Table 4. Phase III UAH engineering design students' survey responses

\begin{tabular}{|c|c|c|c|c|c|}
\hline $\begin{array}{l}\text { 2. Very little } \\
\text { 5. Yes/Very much }\end{array}$ & 1 & 2 & 3 & 4 & 5 \\
\hline $\begin{array}{l}\text { (1) Do you think it is important for US engineering students to work on international } \\
\text { engineering design projects? }\end{array}$ & 0 & 0 & 1 & 3 & 1 \\
\hline $\begin{array}{l}\text { (2) Do you think that as a professional engineer you may have to work with engineers } \\
\text { from other nations? }\end{array}$ & 0 & 0 & 0 & 1 & 4 \\
\hline $\begin{array}{l}\text { (3) Do you think that establishing international engineering design projects may } \\
\text { improve political relations among nations as well? }\end{array}$ & 0 & 0 & 0 & 3 & 2 \\
\hline (4) Have you ever worked on an international design project before? & 4 & 0 & 0 & 0 & 1 \\
\hline $\begin{array}{l}\text { (5) Do you feel that working on the ALLIES design project has prepared you to be a } \\
\text { better engineer? }\end{array}$ & 0 & 0 & 0 & 4 & 1 \\
\hline $\begin{array}{l}\text { (6) Would you have liked to travel to South Africa in affiliation with your ALLIES } \\
\text { project? }\end{array}$ & 2 & 1 & 0 & 0 & 2 \\
\hline $\begin{array}{l}\text { (7) Do you think your ALLIES STEM tool will help South African K-12 students } \\
\text { become motivated to pursue a STEM education? }\end{array}$ & 0 & 0 & 0 & 3 & 2 \\
\hline $\begin{array}{l}\text { (8) Do you think your ALLIES STEM tool can be replicated in South Africa and } \\
\text { distributed to additional K-12 schools? }\end{array}$ & 0 & 0 & 0 & 2 & 3 \\
\hline $\begin{array}{l}\text { (9) Do you have any personal satisfaction knowing that your STEM tool may inspire } \\
\text { South African K-12 students to pursue a STEM education? }\end{array}$ & 0 & 0 & 0 & 3 & 2 \\
\hline
\end{tabular}

\section{Conclusions}

Three phases of the ALLIES partnership have been successfully completed since 2012. As a result, one STEM tool has been donated to a middle school in South Africa and two STEM tools have been donated to schools in North Alabama. Additionally, engineering students at UAH and CPUT have garnered invaluable international design and collaboration experience that results in the acceleration of their ability to do so in the engineering workforce. Survey results indicate a significant learning outcome on behalf of the K-12 students as a result of utilizing the STEM tools. Additionally, a STEM workshop conducted in South Africa impacted educators from 65 schools in the Western Cape region and enabled them to conduct their own STEM outreach events.

\section{Acknowledgements}

The authors gratefully acknowledge the financial support of Northrup Grumman Corporation in the development of the STEM tools. Additionally, Mr. Rhyme Setshedi and Ms. Aisha Abrahams provided critical guidance to CPUT students during the design of the STEM tools and interaction with UAH students and K-12 students in South Africa. The authors are grateful for the UAH and CPUT engineering students and the countless hours invested in design and development of the STEM tools. Finally, much gratitude is extended to the K-12 teachers and students in the US and South Africa; their enthusiasm motivated and inspired everyone involved in the ALLIES partnership. 


\section{References}

$1 \quad$ The Space Foundation. "The Space Report 2014: The Authoritative Guide to Global Space Activity."

2 "Federal Science, Technology, Engineering, and Mathematics (STEM) Education 5-Year Strategic Plan," A Report from the Committee on STEM Education National Science and Technology Council, May 2013, pg.

3 http://www2.ed.gov/about/overview/budget/budget15/crosscuttingissues/stem.pdf

$4 \quad$ http://www.ed.gov/budget15

5 Abdul-Alim, Jamaal, "Black Achievement Stats Belie South Africa's Post-Apartheid Success Story," Diverse Issues in Higher Education, June 24, 2014, http://diverseeducation.com/article/65138/

6 Carmen, C. and Groenewald, B., "Initiation and development of international collaboration among the future space workforce via the design and development of a STEM tool," $63^{\text {rd }}$ International Astronautical Congress Proceedings, Naples, IT, Oct. 2012.

$7 \quad$ Carmen, C. and Fraley, D., "Fostering the Future STEM Workforce Via Industry and Capstone Design Class Partnerships," Proceedings of the ASME 2013 International Mechanical Engineering Congress and Exposition, San Diego, CA, Nov. 13-21, 2013.

$8 \quad$ NASA Systems Engineering Handbook, SP-2007-6105, Revision 1. http://www.acq.osd.mil/se/docs/NASA-SP-2007-6105-Rev-1-Final-31Dec2007.pdf

9 http://www.cput.ac.za/newsroom/news/article/2434/promoting-science-and-technology

10 NASA Educational Resources, "On the Moon Educator Guide," 2009 http://www.nasa.gov/audience/foreducators/topnav/materials/listbytype/On_the_Moon_Guide.html\#.VPyk 8vnF8Qk

11 Terrell, J., Colvard, A., Leahy, K., Beaman, S., Suzuki, R., Harden, J. "Final Design Report: ALLIES Phase III Table Top Wind Tunnel," UAH MAE 491 Product Realization, Dec. 2014

\section{Christina L. Carmen}

Dr. Carmen obtained a Bachelor of Aerospace Engineering degree and a Master of Science in Aerospace Engineering degree from the Georgia Institute of Technology in Atlanta, GA where she conducted research in the area of solid propellants. She obtained a Doctor of Philosophy in Mechanical Engineering from UAH with a focus upon turbulent combustion modeling. Dr. Carmen is the capstone design class coordinator in the MAE department at UAH. She primarily teaches MAE senior design classes with a focus upon product realization - a class she has taught since 2002. Dr. Carmen is the UAH American Society of Mechanical Engineers (ASME) student section faculty advisor as well as a Director of the North Alabama ASME section.

\section{Ben Groenewald}

Ben Groenewald is Head of the EECE Dept. at CPUT in South Africa. He holds a Master of Science in Electrical and Electronic Engineering from the University of Cape Town and is currently studying towards his $\mathrm{PhD}$. He is a panel member of the organizing and editorial committee of the Domestic Use of Energy and the Industrial and Commercial Use of Energy conferences. He is a reviewer for both of these conferences. Mr. Groenewald was the CPUT capstone design class coordinator for many years. His main interest, apart from managing his department, is the promotion of STEM education in South Africa and developing sustainable offgrid electricity supply micro-grid models for rural towns in South Africa. 